\title{
Spatio-temporal variation of the pink shrimp Farfantepenaeus paulensis (Crustacea, Decapoda, Penaeidae) associated to the seasonal overture of the sandbar in a subtropical lagoon
}

\begin{abstract}
Nicolle C. Ferreira \& Andrea S. Freire
Departamento de Ecologia e Zoologia, Centro de Ciências Biológicas, Universidade Federal de Santa Catarina, Campus Universitário, Trindade, 88040-900 Florianópolis, SC, Brazil. (nicollefer@gmail.com; andreasfreire@ yahoo.com.br)

ABSTRACT. On the southern Brazilian coast, the penaeid pink shrimp Farfantepenaeus paulensis (Pérez-Farfante, 1967) is intensively captured by both artisanal and industrial fisheries. In the Ibiraquera Lagoon, artisanal fishing of juvenile stocks has declined sharply over the last 15 years. The traditional management methods used by fishermen are no longer sustainable due to conflicts with the demands of tourism and weak environmental and public agencies. The dynamics of the timing of the artificial opening and natural reformation of a sandbar across the mouth of the lagoon are regarded as a central socio-ecological problem. We evaluated the abundance and biomass variation of $F$. paulensis throughout the year and along a spatial gradient measured from the sandbar into the lagoon. We also explored the influence of opening the sandbar on the shrimp population. Samples were collected monthly from February 2004 to February 2005, using a $27 \mathrm{~mm}$ mesh cast net, in four different areas, with three sites being sampled per area. Small numbers of large shrimps were captured in the upper area, while greater biomass and abundance of small shrimps were observed near the sandbar, suggesting the role of the inner area as a refuge for growing. The highest records for biomass and abundance were recorded during warm months, regardless if the lagoon was open or closed by the sandbar. The Ibiraquera Lagoon could be more productive for fishermen if the sandbar opening was coincident to the period of natural post-larvae influx. Furthermore, coastal stocks could be improved by opening the sandbar again during summer in conjunction with fishing quotas.
\end{abstract}

KEYWORDS. Farfantepenaeus paulensis, coastal lagoon, artisanal fishery, Brazil.

RESUMO. Variação espaço-temporal do camarão rosa Farfantepenaeus paulensis (Crustacea, Decapoda, Penaeidae) associado à abertura sazonal da barra de conexão com o mar em uma lagoa subtropical. $\mathrm{O}$ camarão rosa Farfantepenaeus paulensis (Pérez-Farfante, 1967) é intensivamente capturado, tanto pela frota pesqueira industrial quanto artesanal na costa sul brasileira. Na Lagoa de Ibiraquera (SC), a captura artesanal de camarões tem diminuído gradativamente nos últimos 15 anos. Os métodos de gestão tradicionais utilizados pelos pescadores não são mais eficientes devido aos conflitos com o turismo e a gestão pública e ambiental. A dinâmica de abertura artificial e reestruturação natural do banco de areia no canal de contato da lagoa com o mar é considerada um problema socio-ecológico central no local. Neste estudo foi avaliada a variação na biomassa e abundância do $F$. paulensis ao longo do ano e em um gradiente espacial a partir do canal da barra e até o interior da lagoa. Foram realizadas coletas mensais de fevereiro de 2004 a fevereiro de 2005 com tarrafa de $27 \mathrm{~mm}$ de malha nas quatro lagoas que compõe a Lagoa de Ibiraquera, em três pontos em cada lagoa. Um número pequeno de grandes camarões foi significativamente $(\mathrm{p}<0,05)$ capturado na área mais interna da lagoa, enquanto que maior biomassa e abundância de pequenos camarões foram observadas significativamente $(\mathrm{p}<0,05)$ próximas à barra. Esses resultados sugerem que as áreas mais internas da lagoa funcionam como refúgio para o crescimento das espécies e mostram o papel do canal na migração dos camarões para dentro da lagoa. Os valores de biomassa e abundância foram significativamente $(\mathrm{p}<0,05)$ maiores nos meses mais quentes, independentemente da barra estar aberta ou fechada. O estoque de camarão poderia aumentar caso houvesse uma abertura da barra durante o período natural de entrada de pós-larvas. Além disso, a abertura da barra durante o verão, associada a medidas de conservação das águas do canal da barra, pode implementar os estoques costeiros.

PALAVRAS-CHAVE. Farfantepenaeus paulensis, lagoas costeiras, pesca artesanal, Brasil.

About $25 \%$ of the Brazilian population is concentrated along the coast (512 cities, 13 metropolitan regions) and artisanal fishery is a very important activity from an economic, social and cultural perspective. Traditional approaches for fisheries administration have been incapable of avoiding overexploitation and declining yields (ReIs \& D'INCAO, 2000). The continental shelf of the southern Brazilian coast is one of the most productive fishing areas along the $8,500 \mathrm{~km}$ coast, where a large proportion of commercially important species have life cycles linked to the estuaries. Southwards, the mangrove estuaries become narrower, but the coast shelters a sequence of lagoons parallel to the coast. The artisanal fishery in the coastal lagoons has declined sharply over the last fifty years. For example, in Patos Lagoon estuary fisheries are no longer an economic activity, with the exception of the pink shrimp Farfantepenaeus paulensis (Pérez-Farfante, 1967) and silver mullet (Mugil platanus Günter, 1880) (ReIs \& D'INCAO, 2000).

The distribution range of Farfantepenaeus paulensis is from Cabo de São Tomé (Brazil) $\left(22^{\circ} \mathrm{S}\right)$ to the coastal waters of Buenos Aires (Argentina) $\left(38.5^{\circ} \mathrm{S}\right)$ (Albertoni et al., 2003). The penaeid pink shrimps $F$. paulensis and Farfantepenaeus brasiliensis (Latreille, 1817) are intensively caught by the southern Brazilian fishing fleet. In the late 90's the critical conditions of stocks provoked a crisis in industrial fisheries. This crisis emphasized the need to develop new management practices based on the control of artisanal fisheries, maintain good conditions in the nursery areas and the 
temporary prohibition of shrimp trawling (D'INCAO et al., 2002).

Penaeid shrimps have a complex life cycle, relying on coastal lagoons and estuaries to use as feeding grounds for post-larvae, juveniles and subadults, which subsequently migrate to the sea as subadults or adults (Dall et al., 1990; Pérez-CASTAÑEDA \& Defeo, 2004). These environments constitute nursery habitats that provide food and refuge against predators and support higher growth rates (Minello \& Zimmerman, 1991; Gillanders et al., 2003). Fisheries act on all phases of their life cycle: the artisanal fishery impacts the juvenile population in the estuaries, while industrial fisheries affect the adult stocks in the ocean (VALENTINI et al., 1991). The estuarine phase is characterized by rapid growth and continuous migration to and from the open sea (DALl et al., 1990).

Nowadays, researchers have emphasized the effects of abiotic factors (e.g. temperature) on shrimp biomass (PÉREZ-CASTAÑEDa \& Defeo, 2005). But there is a lack of more detailed studies on the spatial structure of environmental variables and shrimp abundance along an estuarine habitat (PÉREZ-CASTAÑEDA \& DEFEO, 2004).

Penaeid research around the world has mainly been conducted in mangrove estuaries with indo-pacific species. Worldwide, the role of coastal lagoons in the life cycle of penaeid species had been assessed only in Celestun Lagoon, Mexico (Pérez-CAstañeda \& Defeo 2001, 2002, 2003, 2004, 2005) and in Puerto Rico (STONER, 1988). Besides Patos Lagoon, data on the abundance of F. paulensis are available for three lagoons along the Brazilian central coast (ALBERTONI et al., 1999, 2003), two lagoons on the southern Brazilian coast (BRANCO \& Verani, 1998a, b; FAusto \& Fontoura, 1999) and recently in the nearby Conceição Lagoon (LüchmANn et al., 2008).

Coastal lagoons are characterized by their high levels of biodiversity, being environments strongly influenced by the ocean and which are commonly found separated from it by thin sandbars (BARNES, 1980). The state of Santa Catarina has 19 lagoons along its $350 \mathrm{~km}$ coast. In the Ibiraquera Lagoon, which has a semipermanent sandbar that is opened artificially and then reforms naturally, penaeid shrimps are an important artisanal fishery resource.

Since 1970 several management strategies have been employed at the Ibiraquera Lagoon coupled with robust enforcement, such as restrictions of fishing equipment and areas and release of post-larval shrimps (SEIXAS \& BerKes, 2003) However, over the past 15 years, weak social organization of fishermen and poor environmental protection policies has affected fisheries. Despite its natural characteristics and importance for tourism, the Ibiraquera Lagoon has been little studied with no specific oceanographic or biological data to support management planning for the area (BONETTI et al., 2005).

This study attempted to verify the hypothesis that there is no variability in the abundance and biomass of $F$. paulensis throughout the year and along a spatial gradient. The influence of the timing of the artificial opening of the sandbar on the shrimp population was also discussed.

\section{MATERIAL AND METHODS}

Area of study. The Ibiraquera Lagoon is located in the southern Brazilian coast of State of Santa Catarina (28 $26^{\prime} 18^{\prime \prime}-28^{\circ} 10^{\prime} 16^{\prime \prime}$ 'S and 48 $37^{\prime} 44^{\prime \prime}-48^{\circ} 41^{\prime} 53^{\prime \prime} \mathrm{W}$ ) (Fig. 1). Samples were collected in its four subsystems locally called Cima Lagoon (Upper Lagoon), Meio Lagoon (Middle Lagoon), Baixo Lagoon (Lower Lagoon) and Saco Lagoon (Cove Lagoon). The total area of this lagoon is $870 \mathrm{ha}$, with about $9 \mathrm{~km}$ long and a semi-permanent connection to the sea via a 150 meter-wide mouth. The local depth ranges from 0.2 to $2.0 \mathrm{~m}$ and is characterized by sandy bottom; full description can be found at BONETTI et al. (2005).

Sampling procedures and data analysis. Shrimps were collected monthly from February 2004 to February 2005, from 6 to $10 \mathrm{pm}$. The sandbar was opened on February, June and July 2004 and January and February 2005. Three replicate samples were collected at each subsystem of the lagoon using a $27 \mathrm{~mm}$ mesh casting net ( $4.50 \mathrm{~m}$ long, $7 \mathrm{~m}$ in diameter and $30 \mathrm{~m}$ in circumference) covering a $380 \mathrm{~m}^{2}$ area for each sample. This fishing net is the only sampling equipment allowed by the federal environmental protection agency (IBAMA).

Collected shrimps were immediately frozen and transported to the laboratory. Animals were counted, measured to the nearest $0.1 \mathrm{~mm}$ of carapace length (CL) with a caliper, weighed to the nearest $0.01 \mathrm{~g}$ with an analytical balance, and sexed. Shrimps were classed by species according to Pérez-FARFANTE (1970a, b, 1988) and Pérez-Farfante \& Kensley (1997). Shrimps were categorized into recruits $(C L<8.0 \mathrm{~mm})$; juveniles $(8.0 \mathrm{~mm}$ $\leq \mathrm{CL}<15.0 \mathrm{~mm})$; and subadults $(\mathrm{CL} \geq 15.0 \mathrm{~mm})$ according to Pérez-Castañeda \& Defeo (2004). Salinity and temperature were measured at the time of sampling with a refractometer and a thermometer, respectively. Local rainfall data was obtained from Epagri (Empresa de Pesquisa Agropecuária e Extensão Rural de Santa Catarina S.A.).

Data were $\log$-transformed $(\log (x+1))$ to increase the normality of distribution. Two-Way Analysis of Variance (ZAR, 1996) was used to test for statistically significant differences between the lagoon subsystems and between different months, in terms of shrimp biomass and abundance. The Bartlett Test was used a priori to verify homogeneity of variances, and, a posteriori, the Tukey Test was used whenever significant differences were detected between variances.

\section{RESULTS}

Environmental factors. Significant $(p<0.01)$ differences in water temperatures over time defined three distinct periods through the year (Fig. 2): warm months with mean temperatures over $25^{\circ} \mathrm{C}$, intermediate months with mean temperatures from $20^{\circ} \mathrm{C}$ to $25^{\circ} \mathrm{C}$; and cold months with mean temperatures lower than $20^{\circ} \mathrm{C}$. There was little variation in temperature within the four lagoon subsystems. Saco Lagoon had the highest temperature 
$\left(22.8^{\circ} \mathrm{C}\right)$, due to its shallow depth and small area, and Cima Lagoon had the lowest temperature $\left(21.6^{\circ} \mathrm{C}\right)$, both statistically significant.

Salinity levels through the year ranged from 15 $\%$ in December 2004 to $36 \%$ in February 2004 (Fig. 3). After the sandbar was opened, salinity increased significantly in relation to previous months (June and July 2004 and January and February 2005). Mean salinity differed significantly between the four subsystem, ranging from $21.1 \%$ in Cima Lagoon to $25.8 \%$ in Baixo Lagoon.

Rainfall increased from March to May and from October to December (Fig. 3). There was a dry season from June to August and an extremely high level of rainfall in September.

Two seasons were detected with the sandbar open: a warm, salty and wet period and a cold and dry period (Fig. 2-4). The sandbar was closed during mild temperature conditions and salinity decreased in line with rainfall.

Biological data. Three Penaeid species were identified in Ibiraquera Lagoon: the pink shrimps $F$. paulensis, $F$. brasiliensis and the white shrimp Litopenaeus schmitti (Burkenroad, 1936) (Tab. I). Farfantepenaeus paulensis showed the highest frequency, biomass and abundance compared with the other shrimp species in Ibiraquera Lagoon $(8,648$ shrimps were sampled for the study). Only this data was analyzed since the data on other species were not suitable for statistical analysis.

Juveniles and subadults were found in Ibiraquera Lagoon, with carapace lengths (CL) ranging from 10 to $40 \mathrm{~mm}$ with a predominancy of 18 to $24 \mathrm{~mm} \mathrm{CL}$ throughout the year (Fig. 5).

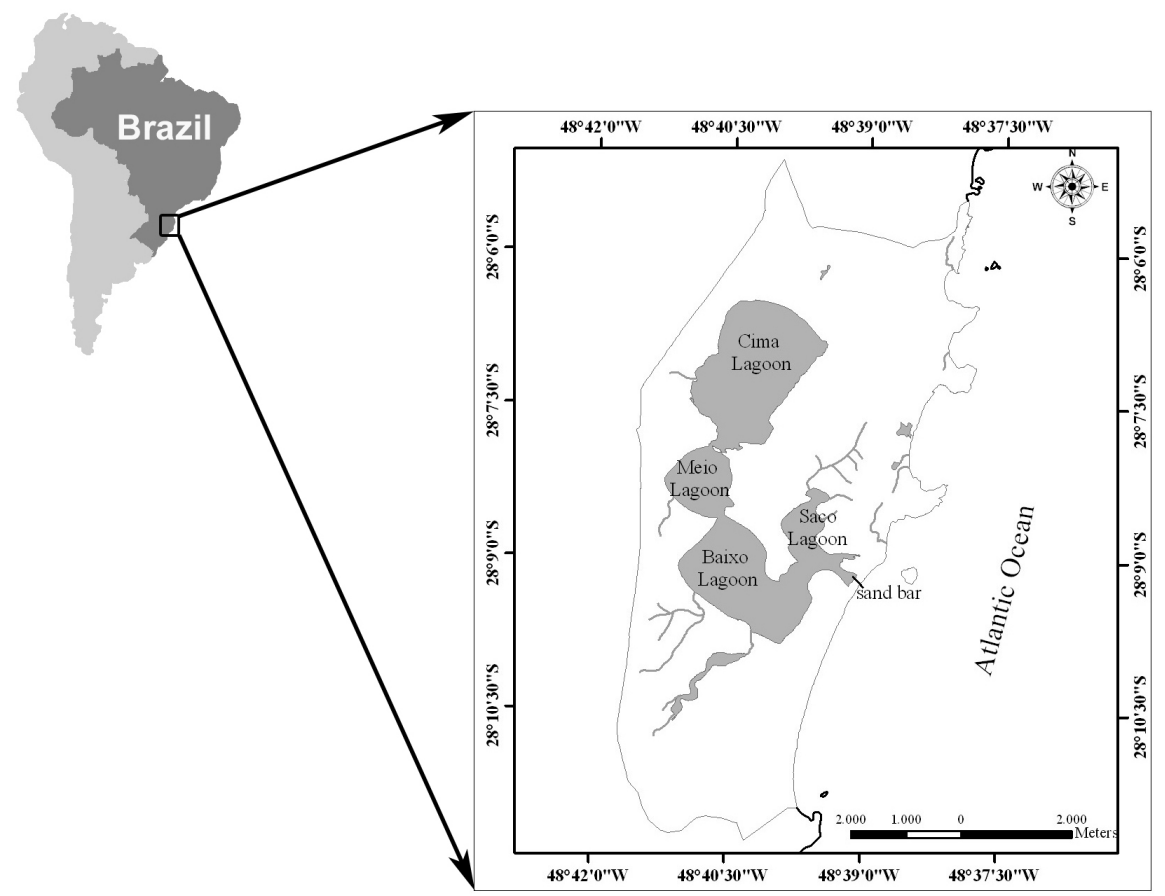

Figure 1. The location of Ibiraquera Lagoon on the Brazilian coast, showing the four subsystems.

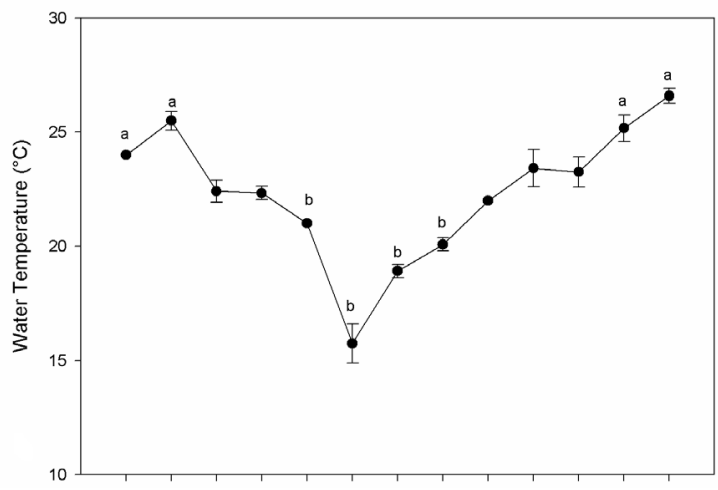

Figure 2. Ibiraquera Lagoon Water temperature $\left({ }^{\circ} \mathrm{C}\right)($ mean $\pm \mathrm{sd})$, warm months (mean temperature over $25^{\circ} \mathrm{C}$ ) and cold months (mean temperature lower than $20^{\circ} \mathrm{C}$ ).

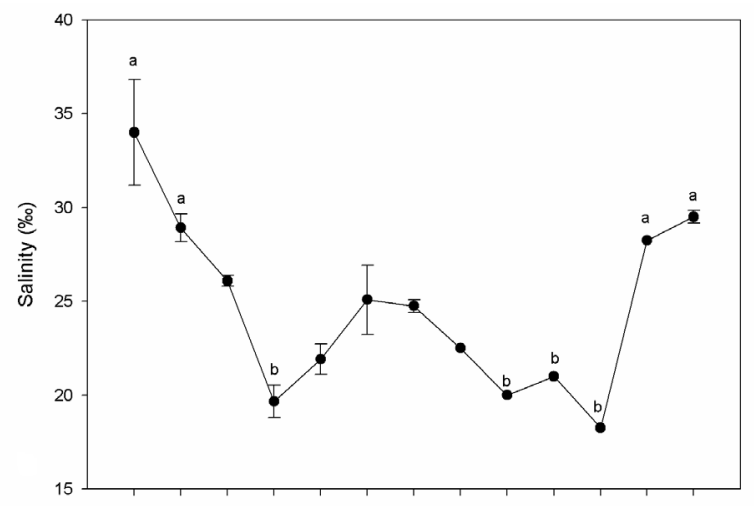

Figure 3. Ibiraquera Lagoon Water salinity $(\% o)$ (mean $\pm \mathrm{sd})$, months with high salinity (26 to $29.5 \%$ ) and months with low salinity (18 to $22 \%$ ). 


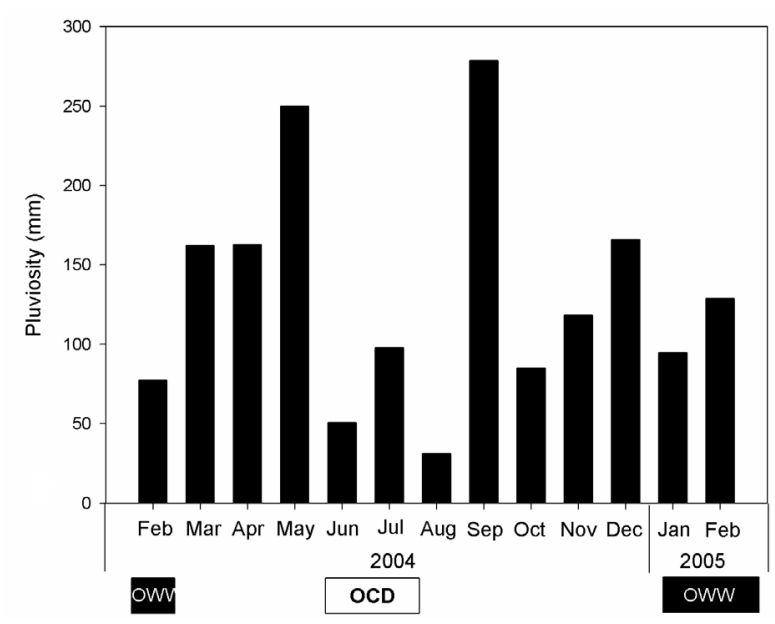

Figure 4. Ibiraquera Lagoon Total monthly rainfall - February 2004 to February 2005. OWW, open sandbar, warm and wet season; OCD, open sandbar, cold and dry season.

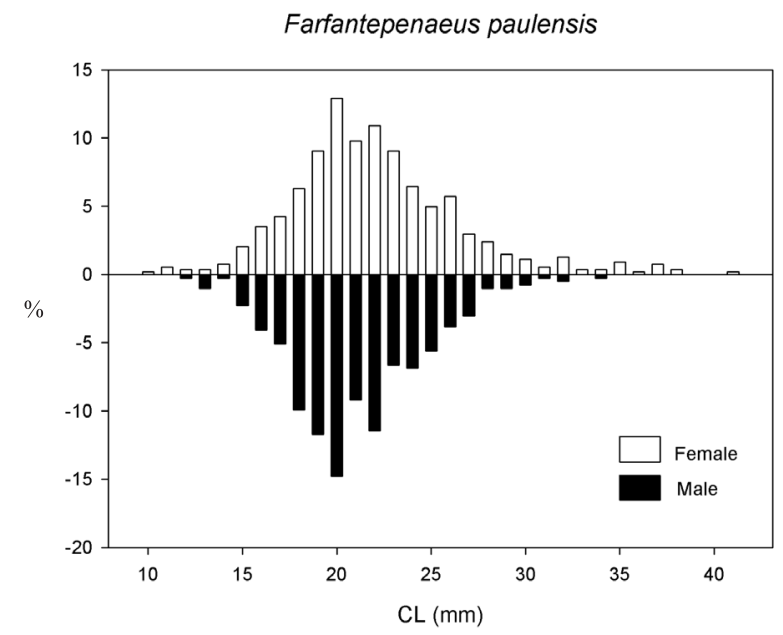

Figure 5. Carapace length (CL) distribution (mm) of Farfantepenaeus paulensis (Pérez-Farfante, 1967) from March 2004 to February 2005 in the Ibiraquera Lagoon for male (solid bars) and female (open bars).

Significant differences $(p<0.01)$ were detected in biomass and abundance within the subsystems (Fig. 6). Cima Lagoon showed the lowest abundance, while Cima and Meio Lagoon had slightly less biomass than the other lagoons. There was a trend for Saco Lagoon to exhibit the highest values for both biomass and abundance. The distribution of CL size in the four subsystems of Ibiraquera Lagoon showed that larger shrimps were found in the Cima Lagoon (Fig. 7).

Biomass and abundance of $F$. paulensis differed significantly $(\mathrm{p}<0.01)$ among months (Fig. 8). Highest biomass and abundance were observed in October 2004 and February 2005 composed by subadults shrimps. All the others months exhibited significantly reduced biomass and low numbers of individuals, composed by juvenile and subadults.
Table I. Relative frequency (RF), biomass and abundance of the shrimp species captured in Ibiraquera Lagoon (Total shrimp captured: $\mathrm{n}=8.648$ ).

\begin{tabular}{lccc}
\hline Species & $\begin{array}{c}\text { RF } \\
(\%)\end{array}$ & $\begin{array}{c}\text { Biomass } \\
(\%)\end{array}$ & $\begin{array}{c}\text { Abundance } \\
(\%)\end{array}$ \\
\hline Farfantepenaeus paulensis & 82 & 96 & 96 \\
Farfantepenaeus brasiliensis & 12 & 3 & 3 \\
Litopenaeus schmitti & 6 & 1 & 1 \\
\hline
\end{tabular}
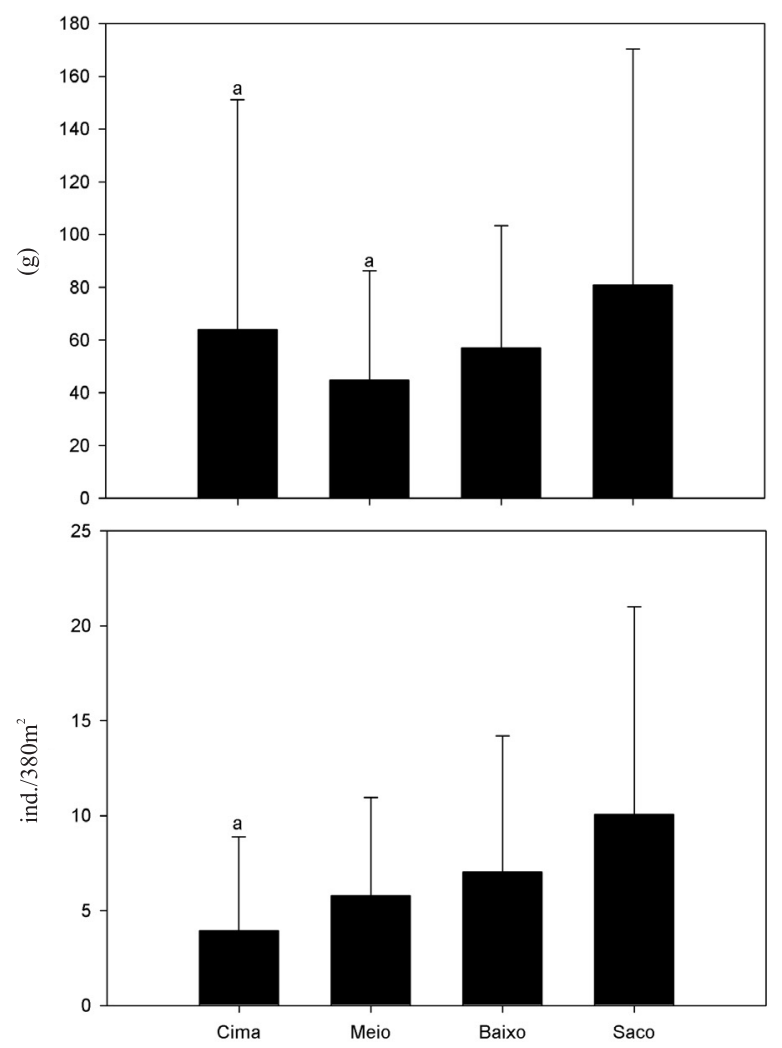

Figure 6. Biomass and abundance (mean \pm sd) of Farfantepenaeus paulensis (Pérez-Farfante, 1967) in the four subsystems of Ibiraquera Lagoon, (a) indicates significant differences among subsystems.

\section{DISCUSSION}

Farfantepenaeus paulensis was the most abundant shrimp species in Ibiraquera Lagoon, since the presence of $F$. brasiliensis in latitudes a little further south is occasional (D'INCAO et al., 2002). This study indicates that throughout the year there was a predominance of subadult stages, as in other southern Brazilian coastal lagoons (e.g. Tramandaí Lagoon (FAusto \& Fontoura, 1999) and Conceição Lagoon (LüCHMANN et al., 2008)).

The difference in the size range of shrimps inhabiting the lagoons, with small shrimps in the Saco Lagoon and large ones in Cima Lagoon, could be due to differences in fishing activity. Personal observations in the area revealed that most of the fishermen are concentrated near the sandbar as they considered the Cima Lagoon damaged by the effluent from Litopenaeus 


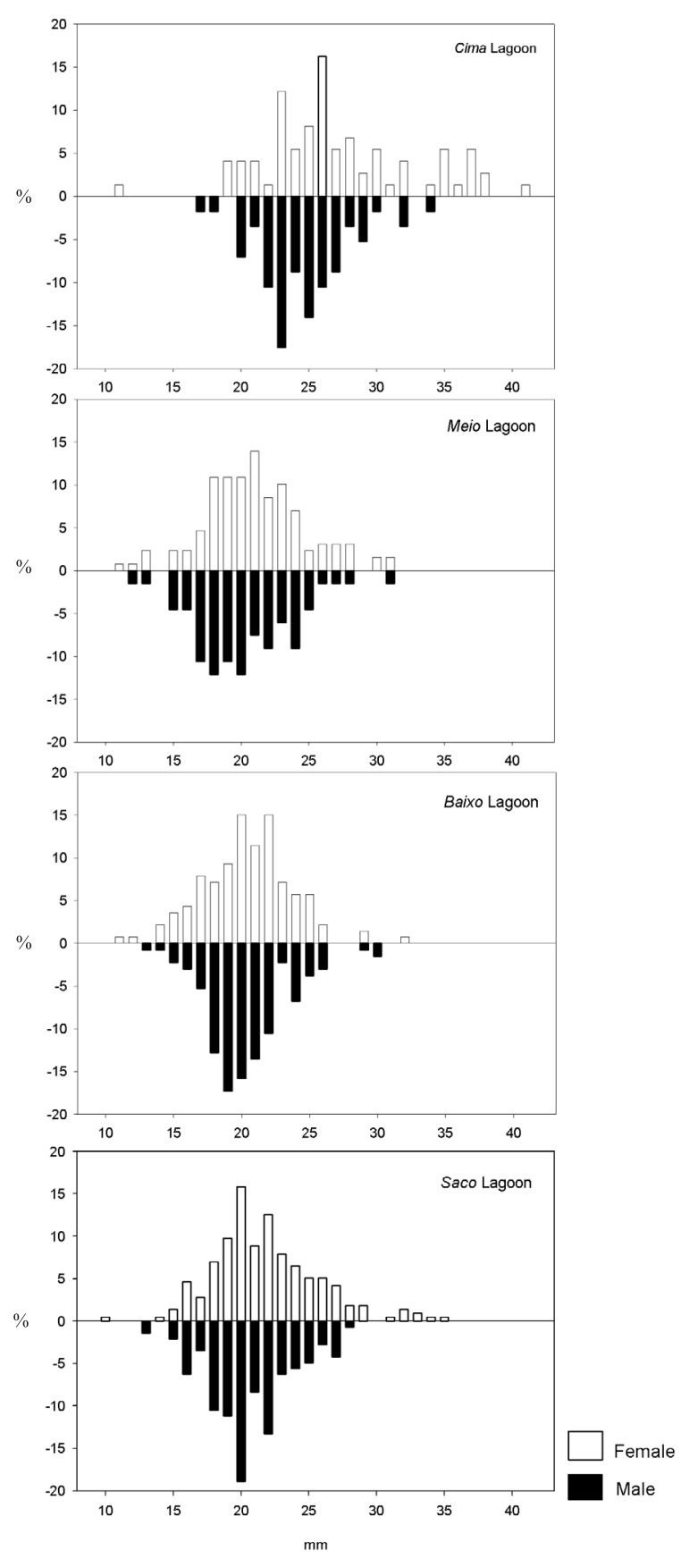

Figure 7. Carapace length (CL) distribution (mm) of Farfantepenaeus paulensis (Pérez-Farfante, 1967) from March 2004 to February 2005 in the four subsystems of Ibiraquera Lagoon for male (solid bars) and female (open bars).

vannamei (Boone, 1931) shrimp farms. Furthermore, access to Cima Lagoon is difficult for opportunist amateur fishermen visiting the area. These size distribution data also give an indication of the migration towards protected and lower salinity areas during the shrimp growth, since Cima Lagoon had the lowest salinity. Farfantepenaeus is known to use habitats in the inner areas as growing grounds (PÉRez-CASTAÑEDa \& DeFeo, 2004). In Conceição Lagoon, large shrimps (F. paulensis and $F$. brasiliensis) occurred in low salinity waters (around 28.5\%o) (BRANCO
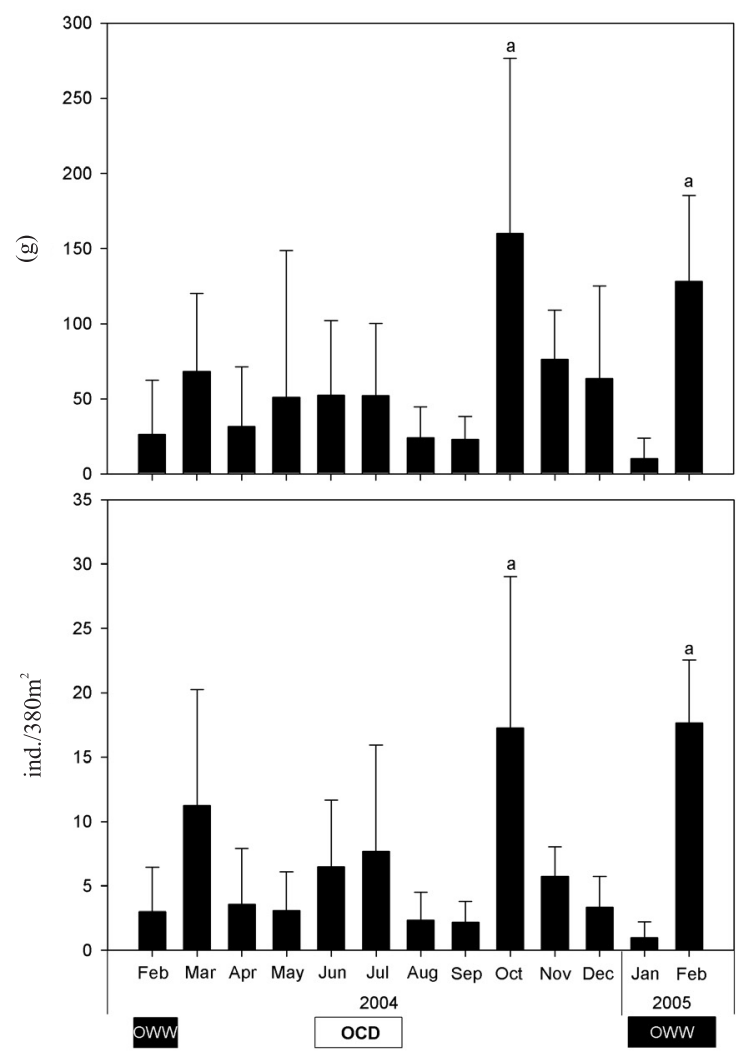

Figure 8. Biomass (mean \pm sd) and abundance (mean \pm sd) of Farfantepenaeus paulensis (Pérez-Farfante, 1967) in Ibiraquera Lagoon from February 2004 to February 2005, (a) indicates significant differences among months.

\& Verani, 1998a, b). D'Incao (1991) reported that $F$. paulensis prefer areas with salinity under $10 \%$ and argued that migratory activity seawards initiated when shrimps reached 4 or 5 months old (total length of $7 \mathrm{~cm}$ ). However, this species can remain in the estuary for longer periods (up to 10 months) without any apparent problems for its growth and development (D'INCAO, 1991).

The range of salinity in Ibiraquera Lagoon was within optimal limits for Farfantepenaeus species survival, according to Pérez-Castañeda \& Defeo (2005). Farfantepenaeus shrimps showed high abundance in conjunction with high temperature in Celestun Lagoon (PÉrez-Castañeda \& Defeo, 2002), in Conceição Lagoon (LüChMANn et al., 2008) and Patos Lagoon (D' InCAO, 1991). In this study F. paulensis biomass and abundance became also higher with the temperature increase.

The large numbers of shrimps sampled in October, when the sandbar was closed, suggested that post-larvae entered in the Lagoon between June and July when the sandbar was open. From October to December the intense fishing activity together with the closure of the sandbar, caused biomass and abundance decrease. The opening of the sandbar in the January 2005 allowed the migration of shrimps towards the inner subsystems of Ibiraquera Lagoon, and therefore enhancing shrimp biomass and abundance in February.

Studying the growth of $F$. paulensis D'INCAO (1983) determined that post-larvae input to estuarine waters along the southern Brazilian coast started in late 
September and occurred mainly in October/November. Post-larvae entrance into Patos Lagoon was not registered during winter (Antunes, 1997 apud FAUSTO \& FONTOURA, 1999). This study suggests that there was a post-larvae input in June and July but only after September, when the temperature started to rise, the conditions were suitable for shrimp growth, providing the capture in October.

The open sandbar in March 2004 and February 2005 allowed juveniles and subadults to migrate to the ocean and resupply the ocean stock. Fishery activity continued whenever shrimps were present, regardless of whether they were still growing (after March), if there would be no further input (after October) or if they were migrating to the lagoon and to the sea (after January). According to Almeida \& D' Incao (1999) artisanal fishery in Patos Lagoon affects juvenile stock in a very intense manner, practically restricting migration of shrimps to the ocean. This trend is also seen in other estuaries and could cause a lack of adult stock recruitment (VALENTINI et al., 1991).

It is a common idea among local fisherman that shrimp is no longer an economic resource in the area. Therefore, urgent management procedures are needed in the area; there is still a representative and impoverished fisherman community, and this lagoon also contributes to the collapsed adult stock in the sea. Although small, the Ibiraquera Lagoon, is one of the nursery habitats that has been least modified by human activity on the nearby coast.

The connection between estuaries and the coastal fishing grounds is already well known (GILLANDERs et al., 2003). The coast of Santa Catarina State is considered one of the two major congregation zones for $F$. paulensis in Brazilian coast. Recent work described the unique population genetic profile of the southern pink shrimp, describing a southern stock from Santa Catarina coast to Patos Lagoon (GusMão et al., 2005).

Older local fishermen understand that the renewal of the lagoon fishery stock depends on the season when the channel is open. Fishermen opened the channel in the spring (around September and October) which is the season of the post-larvae pink shrimp in the nearby ocean; in summer (between December and February) which is the season of small mullet; and in the late fall (between May and June) which is the season of large adult mullet and pink shrimp post-larvae (SEIXAS \& BERKES, 2003).

Nowadays, there is no longer agreement about when the sandbar should be opened and the demands of tourism are becoming more important than ecological arguments. In a tropical lagoon in the Brazilian coast, scientific results suggested the opening of the sandbar together with the input of post-larvae (ALBERTONi et al., 1999). In another area, conflicts between fishermen in relation to sandbar opening resulted in low yields (LIMA et al., 2001). We suggest that the sandbar should be opened in late spring, summer and late fall to combine the traditional fishermen's knowledge with the scientific data from our work. We also suggest that shrimp fishing activity in Saco Lagoon should be low or even restricted when the sandbar is open, to allow major recruitment to the lagoon and migration to the sea. Special care should be devoted to the Cima Lagoon due to its growing ground role. Our findings will be reported at the Local Agenda 21 Forum to improve management initiatives in the area.
Acknowledgments. This research was supported by a grant from the Fundo Nacional do Meio Ambiente (FNMA). We are grateful to Prof. Paulo Freire Vieira NMD (Núcleo Interdisciplinar de Meio Ambiente e Desenvolvimento/ UFSC) coordinator of the project "Fisheries Management in the Ibiraquera Lagoon, SC". We are grateful to the local fisherman Eduardo Sampaio for his help during field work. We are also grateful to Fórum da Agenda 21 in Ibiraquera and the local traditional leaders. This work was part of the first author's final project for an Aquaculture Engineering degree at UFSC.

\section{REFERENCES}

Albertoni, E. F.; Palma-Silva, C. \& Esteves, F. A. 1999. Larvae and post-larvae of Penaeidae and Palaemonidae in coastal lagoons of the north of Rio de Janeiro (Macaé, RJ). Revista Brasileira de Biologia 59(1):109-117.

2003. Crescimento e fator de condição na fase juvenil de Farfantepenaeus brasiliensis (Latreille) e F. paulensis (PérezFarfante) (Crustacea, Decapoda, Penaeidae) em uma lagoa costeira tropical do Rio de Janeiro, Brasil. Revista Brasileira de Zoologia 20(3):409-418.

Almeida, H. L. P. S. \& D'Incao, F. 1999. Análise do esforço de pesca do camarão-rosa (Farfantepenaeus paulensis) na Lagoa dos Patos, Brasil. Atlântica 21:77-92.

Barnes, R. S. K. 1980. Coastal Lagoons. Cambridge, Cambridge University. $106 \mathrm{p}$

Bonetti, C.; Bonetti, J. \& Beltrame, E. 2005. Mudanças nas características composicionais das águas da Lagoa de Ibiraquera (SC) em resposta a dinâmica de abertura e fechamento de sua desembocadura. Brazilian Journal of Aquatic Science and Technology 9(2):39-47.

Branco, J. O. \& Verani, J. R. 1998a. Estudo populacional do Camarão-Rosa Penaeus paulensis Pérez Farfante (Natantia, Penaeidae) na Lagoa da Conceição, Santa Catarina, Brasil. Revista Brasileira de Zoologia 15(2):353-364.

1998b. Aspectos bioecológicos do Camarão-Rosa Penaeus brasiliensis Latreille (Natantia, Penaeidae) da Lagoa da Conceição, Florianópolis, Santa Catarina, Brasil. Revista Brasileira de Zoologia 15(2):345-351.

Dall, W.; Hill, B. J.; Rothlisberg, P. C. \& Sharple, D. J. 1990. The biology of the Penaeidae. Advances in Marine Biology 27:489p.

D'Incao, F. 1991. Pesca e biologia de Penaeus paulensis na Lagoa dos Patos, RS. Atlântica 13(1):159-169.

D'Incao, F.; Valentini, H. \& Rodrigues, L. F. 2002 Avaliação da pesca de camarões nas regiões sudeste e sul do Brasil 19651999. Atlântica 24(2):103-116.

FAusto, I. V. \& FontourA, N. F. 1999. Abundância sazonal do camarão-rosa Farfantepenaeus paulensis na Laguna Tramandaí, RS, Brasil (Crustacea, Decapoda, Penaeidae). Nauplius 7:93-111.

Gillanders, B. M.; Able, K. W.; Brown, J. A.; Eggleston, D. B. \& SHERIDAN, P. F. 2003. Evidence of connectivity between juvenile and adult habitats for mobile marine fauna: an important component of nurseries. Marine Ecology Progress Series 247:281-295.

Gusmão, J.; Lazoski, C. \& Solé-Cava, A. M. 2005. Population genetic structure of Brazilian shrimp species (Farfantepenaeus sp., F. brasiliensis, F. paulensis and Litopenaeus schmitti: Decapoda: Penaeidae). Genetics and Molecular Biology 28(1): $165-171$.

Lima, N. R. W.; Bizerril, C. R. S. F.; Caniçali, M. R.; Suzuki, M. S. \& Assumpção, J. 2001. Atividade de Pesca durante a abertura da barra da Lagoa de Iquipari, São João da Barra, RJ. Boletim do Instituto de Pesca 27(2):191-200.

Lüchmann, K. H.; Freire, A. S.; Ferreira, N. C.; Daura-Jorge, F. G. \& Marques, M. R. F. 2008. Spatial and temporal variations in abundance and biomass of penaeid shrimps in the subtropical Conceição Lagoon, southern Brazil. Journal of the Marine Biological Association of the United Kingdom 88:293-300.

Minello, T. J. \& Zimmerman, R. J. 1991. The role of estuarine habitats in regulating growth and survival of juvenile penaeid shrimp. In: Deloach, P. F.; Dougherty, W. J. \& Davidson, M. A eds. Frontiers of shrimp research. New York, Elsevier. p.1-16. 
Pérez-Castañeda, R. \& Defeo, O. 2001. Population variability of four sympatric penaeid shrimps (Farfantepanaeus spp.) in a tropical coastal lagoon of Mexico. Estuarine, Coastal and Shelf Science 52:631-641.

2002. Morphometric relationships of penaeid shrimps in a coastal lagoon: Spatio-temporal variability and management implications. Estuaries 25(2):282-287.

2003. Influence of estuarine zonation on exploited shrimp population in a Mexican biosphere reserve: a feature for management and conservation. Journal of the Marine Biological Association of the United Kingdom 83:781784.

2004. Spatial distribution and structure along ecological gradients: penaeid shrimps in a tropical estuarine habitat of Mexico. Marine Ecology Progress Series 273:173-185.

2005. Growth and mortality of transient shrimp populations (Farfantepenaeus spp.) in a coastal lagoon of Mexico: role of the environment and density-dependence. Journal of Marine Science 62:14-24.

PÉrez-Farfante, I. 1970a. Diagnostic Characters of juveniles of the shrimps Penaeus aztecus aztecus, $P$. duorarum, and $P$. brasiliensis (Crustacea, Decapoda, Penaeidae). U.S.Fish wildlife Service, Special Scientific Report. Fisheries 599:26p.

1970b. Características diagnósticas de los juveliles de Penaeus aztecus subtilis, Penaeus duorarum notialis y Penaeus brasiliensis (Crustacea, Decapoda, Penaeidae).
Separatas Memorias Sociedad Ciencias Naturales La Salle 30:159-182.

1988. Illustrated key to Penaeoid of commerce in the Americas. NOAA TechnicalReport NMFS 64:32p.

Pérez-Farfante, I. \& Kensley, B. 1997. Penaeoid and Sergestoid Shrimps and prawns of world. Keys and diagnoses for the families and genera. Paris, Ed. Du Museum. 235p.

Reis E. G. \& D'Incao F. 2000. The present status of artisanal fisheries of extreme Southern Brazil: an effort towards community-based management. Ocean \& Coastal Management 43:585-595.

Seixas, C. S. \& Berkes, F. 2003. Learning From Fishers: Local Knowledge for Management Design and Assessment. In: VIEIRA, P. F. org. Conservação da Diversidade Biológica e Cultural em Zonas Costeiras: Enfoques e experiências na América Latina e no Caribe. Florianópolis, Ed. APED. p.333-371.

Stoner, A. W. 1988. A nursery ground for four tropical Penaeus species: Laguna Joyuda, Puerto Rico. Marine Ecology Progress Series 42:133-141.

Valentini, H.; D’Incao, F.; Rodrigues, L. F.; Neto, J. E. R. \& Rahn, E. 1991. Análise da pesca do camarão-rosa (Penaeus brasiliensis e Penaeus paulensis) nas regiões sudeste e sul do Brasil. Atlântica 13(1):143-157.

Zar, J. H. 1996 Biostatistical Analysis, 3rd ed. New Jersey, Prentice Hall. 662p.

Recebido em outubro de 2007. Aceito em agosto de 2008. ISSN 0073-4721

Artigo disponível em: www.scielo.br/isz 